\title{
No relationship between gastrointestinal parasite intensities or mercury burdens on fluctuating asymmetry in Common Eider (Somateria mollissima) mandibles
}

\author{
Corey A. Scobie ${ }^{1}{ }^{*}$, Jesser G. Panopi ${ }^{2}$, Erin M. Bayne ${ }^{2}$, Jennifer F. Provencher ${ }^{3}$, and \\ H. Grant GiLChrist ${ }^{4}$
}

${ }^{1}$ Royal Alberta Museum, 9810-103a Avenue NW, Edmonton, Alberta T5J 0G2 Canada

${ }^{2}$ Department of Biological Sciences, University of Alberta, CW405 Biological Sciences Building, Edmonton, Alberta T6G 2E9 Canada

${ }^{3}$ Department of Biology, Carleton University, 1125 Colonel By Drive, Raven Road, Ottawa, Ontario K1A 0H3 Canada

${ }^{4}$ National Wildlife Research Centre, Environment and Climate Change Canada, 1125 Colonel By Drive, Raven Road, Ottawa, Ontario K1 A 0H3 Canada

*Corresponding author: Corey.Scobie@gov.ab.ca

Scobie, C.A., J.G. Panopi, E.M. Bayne, J.F. Provencher, and H.G. Gilchrist. 2020. No relationship between gastrointestinal parasite intensities or mercury burdens on fluctuating asymmetry in Common Eider (Somateria mollissima) mandibles. Canadian Field-Naturalist 134(2): 136-143. https://doi.org/10.22621/cfn.v134i2.2325

\begin{abstract}
Mercury (Hg) emissions have increased since 1950 and biomagnification in Arctic ecosystems can affect animals, particularly at higher trophic levels. Exposure to $\mathrm{Hg}$ can negatively affect young developing animals, resulting in altered morphology and ultimately, lower fitness. We examined the relationship of mandible fluctuating asymmetry (FA) with gastrointestinal helminth intensity and breast muscle $\mathrm{Hg}$ concentration in Common Eider (Somateria mollissima borealis). Procrustes analysis of variance indicated significant FA but relatively high measurement error. Based on multiple linear regression modelling, there was no significant relationship between FA and $\mathrm{Hg}$ concentration or parasite burden. There may be a mismatch in trying to relate amount of $\mathrm{Hg}$ and parasite intensity in adults to FA that would have occurred early in life during skeletal development.
\end{abstract}

Key words: Mercury; parasite; Common Eider; fluctuating asymmetry; skeletal asymmetry; Somateria mollissima

\section{Introduction}

Mercury $(\mathrm{Hg})$ emissions have increased since 1950, primarily due to coal combustion (Streets et al. 2011). In the atmosphere, emitted $\mathrm{Hg}$ may undergo reactions that result in the deposition of $\mathrm{Hg}$ onto the land and oceans (Krabbenhoft and Sunderland 2013). Deposited Hg is then methylated and converted into methylmercury (MeHg), which may accumulate across trophic levels, particularly in aquatic food webs (AMAP 2011; Krabbenhoft and Sunderland 2013). Methylmercury is the most toxic form of mercury to animals. In the Arctic, it is estimated that $74.2-94.4 \%$ of $\mathrm{Hg}$ in animals originates from an anthropogenic source (Dietz et al. 2009).

Like other contaminants, $\mathrm{Hg}$ can affect biological processes such as function of the central nervous system, hormonal regulation, and reproduction in animals. Mercury toxicity in birds often results in lower reproductive output, detrimental nesting behaviour, re- duction in feeding rates, and thereby reduced juvenile survival (Scheuhammer et al. 2007). Compiled experimental and correlational studies also reveal Hg's adverse impacts on avian reproduction, behaviour, endocrine system, and immunocompetence (Whitney and Cristol 2018).

In general, reduced immune function caused by contaminants may increase host susceptibility to parasites (Sures 2006) and several studies have linked increased parasite load with higher $\mathrm{Hg}$ exposure. For instance, Glaucous Gulls (Larus hyperboreus) show higher acanthocephalan parasite intensities with higher Hg levels (Sagerup et al. 2009). Zebra Finches (Taeniopygia guttata) provided with $\mathrm{MeHg}$ in their diet showed greater coccidian parasite intensities instead of lower parasite intensities during the anticipated parasite expulsion timeframe (Smith et al. 2018).

Fluctuating asymmetry (FA; Klingenberg 2015) is a biological assessment that has been used to de- 
termine contaminant and parasite impacts on animals (Møller 1992; Jenssen et al. 2010; RodríguezGonzález et al. 2020). FA refers to the structural discrepancies in left-right sides of a structure and its divergence from the expected ideal phenotype during an organism's development (Klingenberg 2003; Nijhout and Davidowitz 2003). FA studies focus on the idea that environmental stress lowers the individual's ability to mitigate the developmental variations on each side of the organism, resulting in higher asymmetry between the two sides of an organism's structure (Klingenberg 2015). For instance, studies on small mammals reported higher levels of skull FA with increased exposure to environmental contaminants (Oleksyk et al. 2004; Sánchez-Chardi et al. 2013; Yalkovskaya et al. 2016).

In this study, we evaluated the relationship between individual FA values, $\mathrm{Hg}$ content, and parasite intensity in Common Eider (Somateria mollissima borealis). Common Eiders are sea ducks found in coastal regions in the Arctic and subarctic zones (Goudie et al. 2000). Bivalves, gastropods, and crustaceans comprise the majority of prey items that eiders consume (Waltho and Coulson 2015). Common Eiders often become infected with endoparasitic helminths such as acanthocephalans and cestodes through their consumption of intermediate crustacean hosts such as amphipods (Friend and Franson 1999; McLaughlin 2008; Nikolov et al. 2008). The endoparasites harboured by eiders include different species of digeneans, cestodes, acanthocephalans, and nematodes (Bishop and Threlfall 1971; Borgsteede et al. 2005). Wayland et al. (2001a) showed that in the Canadian Arctic, nematode numbers increase with higher $\mathrm{Hg}$ levels in Common Eiders. Parasite stress in Common Eider ducklings are also known to reduce nutrient availability and cause inflammation of the intestinal mucosa (Hollmén et al. 1999). Parasites may impede the intake of necessary nutrients by inducing mucosa layer damage in the gastrointestinal tract (Hollmén et al. 1999).

Overall, the stresses induced by $\mathrm{Hg}$ contamination and the resulting parasite intensity during development in young Common Eiders might reduce the ability of individuals to alleviate developmental variations on the skull, leading to higher observable FA in adults. Therefore, we predicted greater FA in the skulls of adult Common Eiders with higher levels of $\mathrm{Hg}$ and greater gastrointestinal parasite intensity. In this study, we assumed that the $\mathrm{Hg}$ concentration and parasite intensity in adults reflects $\mathrm{Hg}$ exposure and parasites during development.

\section{Methods}

Eiders were collected in Cape Dorset, Nunavut in May 2011 as part of the annual Indigenous hunt. We used the skulls from 39 adult male Common Eiders, along with the corresponding wing chord $(\mathrm{cm})$, total $\mathrm{Hg}$ (dry weight) in pectoral muscle tissue, and genus level helminth parasite intensity for each individual (see Provencher et al. [2016] for additional details of methods used to determine amount of mercury and parasite intensity; the parasite intensity parameter Provencher et al. [2016] used included non-infected birds that both Margolis et al. [1982] and Rózsa et al. [2000] consider to be parasite abundance, not intensity). The skin was removed from the cranium and lower mandible of each specimen, which were then cleaned by Dermestid Beetles (Dermestes maculatus) and bleached with 3\% hydrogen peroxide.

Landmarks (distinct locations for three dimensional measurements) chosen for FA analysis for vertebrate skulls often try to capture the whole shape of the skull (Oleksyk et al. 2004; Urošević et al. 2015; del Castillo et al. 2016). Mandibles were chosen for digitization rather than the whole skull because past FA studies show that the greatest potential effects of contaminants are on mandible FA (Sánchez-Chardi et al. 2013; Yalkovskaya et al. 2016). As mentioned in Klingenberg (2015), structures that have object symmetry, like skulls, should possess single landmarks on the midline of the structure and paired landmarks on the left and right side of the structure to ensure the required data are gathered for the analyses. Based on these criteria, we chose dorsal, lateral, and ventral landmarks that reflected the overall mandible shape. Measurement errors that can affect FA analysis are often associated with difficulty in finding and distinguishing the landmarks on the structure (Klingenberg 2015). To reduce the likelihood of measurement errors, the locations of the landmarks in this study were chosen because they were easily distinguished and past studies have found them to be repeatable.

In total, 20 landmarks were digitized on 39 mandibles (Figures 1 and 2; Table 1) using a MicroScribe 3D Digitizer (Solution Technologies Inc., Oella, Maryland, USA). Ten mandibles (26\%) were digitized twice to calculate measurement error. Mandibles were secured in modelling clay on a raised wooden platform $(11.0 \mathrm{~cm}$ tall $\times 4.5 \mathrm{~cm}$ wide $\times 9.7 \mathrm{~cm}$ long $)$ clamped to a steady table. An elastic further secured the mandible by holding it between landmarks 5 and 9, 15 and the platform. All landmark digitization occurred from October 2017 to August 2018 and was performed by J.G.P.

Procrustes fit and Procrustes ANOVA (analysis of variance) in program MorphoJ (Klingenberg 2011) was used to acquire FA scores. The Procrustes fit removes configurational size, position and orientation differences, and determines shape differences among individuals (Klingenberg 2015). A Procrustes 


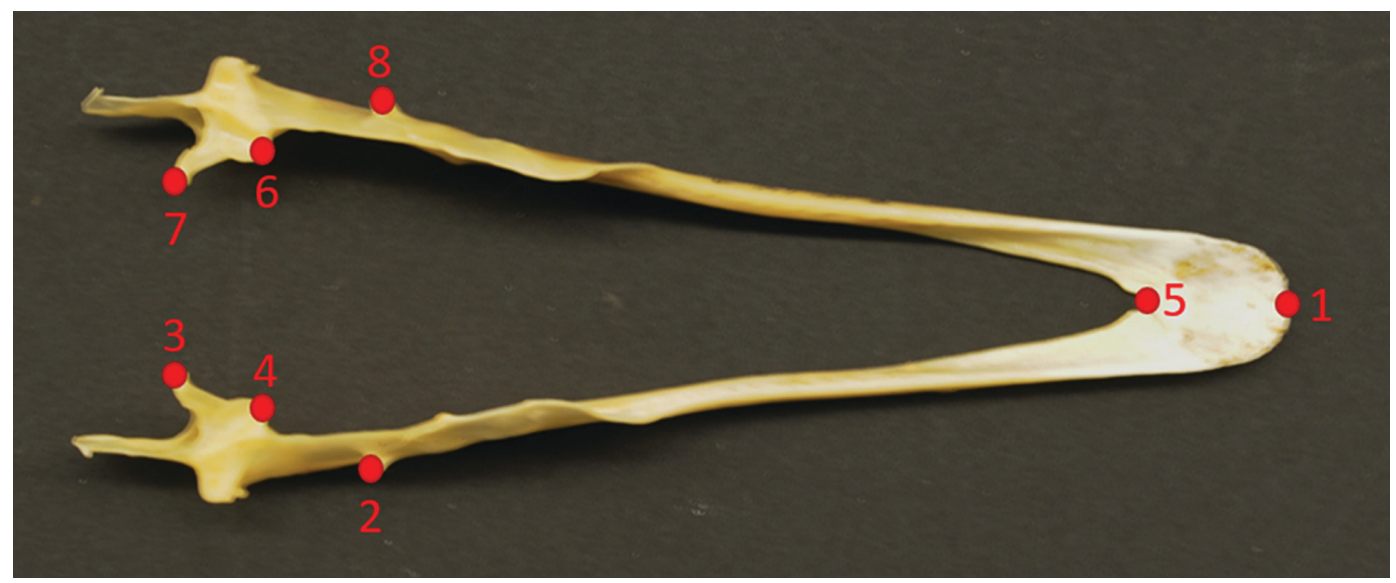

Figure 1. Landmarks on the dorsal surface of a Common Eider (Somateria mollissima) mandible. Photo: C.A. Scobie.

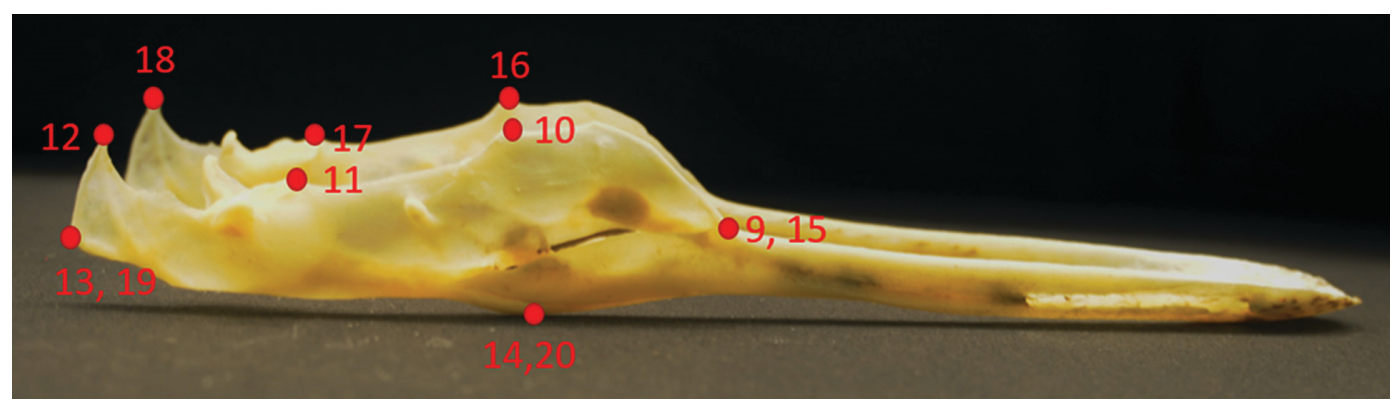

FigURE 2. Landmarks on the lateral surface of a Common Eider (Somateria mollissima) mandible. Landmarks with two numbers associated with it are replicated in the same area on the opposite lateral surface of the mandible. Photo: C.A. Scobie.

TABLE 1. Landmark definitions on the lateral and dorsal surfaces of the Common Eider (Somateria mollissima) mandible.

\begin{tabular}{ll}
\hline \hline No. & \multicolumn{1}{c}{ Definition } \\
\hline Dorsal & Tip of dentary (adjacent to the very anterior point where dentary splits into two) \\
1 & Supra-angular \\
3,7 & Very posterior tip of the protruding process towards the inside of the mandible in the angular/articular region \\
4,6 & Most anterior tip of the protruding process towards the inside of the mandible in the angular/articular region \\
5 & Most posterior point where the dentary splits into two (adjacent with dentary tip) \\
Lateral & Point where the dentary articulates with the other bones. Point directly adjacent to the vacuity, occurs at the \\
9,15 & -
\end{tabular}

fit was selected with alignment with the principal axes. A Procrustes ANOVA was then used to acquire FA values for each individual, with the assumption that isotropic variation at all landmarks was identical. Procrustes ANOVA uses the total variation derived from the differences between each individual config- 
uration and the average configuration and allocates it into individual, reflection (comparison of sides of symmetrical object), and the interaction between individuals and reflection variation, as well as measurement error (Klingenberg et al. 2002). MorphoJ provides individual FA values as Procrustes FA values or Mahalanobis distances (Klingenberg and Monteiro 2005; Klingenberg 2011).

Total $\mathrm{Hg}$ was measured from muscle tissue from the left pectoral muscle of each eider. Most of the total $\mathrm{Hg}$ found in aquatic birds is comprised of the toxic form (MeHg; Houserova et al. 2007), so we used total $\mathrm{Hg}$ in our analyses with the assumption that most was likely MeHg. The intestines of each eider were examined thoroughly and all helminths found were identified to genus. Initial dataset exploration showed right-skewed counts for Lateriporus (cestode or tape worm), Microsomacanthus (cestode), and Profilicollis (acanthocephalan or spiny-headed worm) data. These data were log-transformed to remove non-normality. Program STATA 11 (StataCorp 2009) was used to perform a multiple linear regression analysis involving $\mathrm{Hg}$ concentration $(\mathrm{Hg} / \mathrm{g}$ of dry weight) and parasite intensity for log-Lateriporus, log-Microsomacanthus, and log-Profilicollis and categorical variables Fimbriarioides (a cestode), unidentified cestode, in relation to Mahalanobis distances measuring FA, while controlling for wing length.

\section{Results}

The analysis indicated highly significant variation in symmetry among individuals $\left(F_{1026,988}=6.72, P<\right.$ 0.0001 ; Table 2). Similarly, directional asymmetry or the variation among reflections was significant $\left(F_{26,988}\right.$ $=47.80, P<0.0001$; Table 2 ), which means there was variation among averages of the two sides of the left and right side of the mandibles. The analysis also showed significant $\mathrm{FA}$ or reflection variations among individuals $\left(F_{988,477}=2.43, P<0.0001\right.$; Table 2$)$, indicating a difference between the average of all left sides and all right sides of the mandibles. The $F$-value for the interaction between individual and reflection (Table 2) indicates the magnitude of FA relative to the measurement error (Klingenberg 2015). Our F-ratio indicates that measurement error was relatively high, but twice as much variation was explained by FA than measurement error (Table 2).

Mercury was detected in the muscle tissue of all eiders and they had an average concentration of 0.7 $\mu \mathrm{g} / \mathrm{g}$ dry weight (Table 3). Parasite intensity and $\mathrm{Hg}$ concentration did not significantly predict variation in Mahalanobis distances $\left(R^{2}=0.17, F_{7,31}=0.90, P=\right.$ 0.51 ; Table 3). An apparent positive relationship between mercury and FA (Figure 3; Table 3) was not significant $\left(t_{38}=1.81, P=0.08\right)$.

\section{Discussion}

We did not find a significant relationship between

TABLE 2. Procrustes ANOVA results for adult male Common Eider (Somateria mollissima) mandibles assuming identical isotropic variation for all landmarks. Results include analyses of digitized left and right sides of 39 mandibles, each with nine paired landmarks and two median landmarks.

\begin{tabular}{lccrrr}
\hline \hline \multicolumn{1}{c}{ Variables } & SS & MS & df & \multicolumn{1}{c}{$F$} & $P$ \\
\hline Individual & 0.140 & 0.00014 & 1026 & 6.72 & $<0.0001$ \\
Reflection & 0.025 & 0.00097 & 26 & 47.80 & $<0.0001$ \\
Ind $\times$ Reflection & 0.020 & 0.00002 & 988 & 2.43 & $<0.0001$ \\
Error & 0.004 & 0.00001 & 477 & & \\
\hline \hline
\end{tabular}

TABLE 3. Results of multiple linear regression analysis looking at Mahalanobis fluctuating asymmetry values of 39 adult male Common Eider (Somateria mollissima) mandibles from Cape Dorset, Nunavut, Canada in relation to mercury content and parasite intensity. Descriptive statistics are also provided for variables included in the model: average (median for parasite intensity), range of variables, and prevalence of each type of parasite.

\begin{tabular}{lrcclc}
\hline \hline Variable & $\beta$ & SE & $P$ & \multicolumn{1}{c}{ Average (range) } & Prevalence (\%) \\
\hline Wing & -0.14 & 0.10 & 0.18 & $29.5 \mathrm{~cm}(27.5-31.1)$ & - \\
Mercury & 0.67 & 0.37 & 0.08 & $0.7 \mu \mathrm{g} / \mathrm{g}(0.3-1.2)$ & 90 \\
Lateriporus (cestode) & -0.07 & 0.07 & 0.36 & $9(0-191)$ & 69 \\
Profilicollis (acanthocephalan) & 0.01 & 0.06 & 0.87 & $4.5(0-144)$ & 3 \\
Fimbriarioides (cestode) & -0.22 & 0.74 & 0.11 & $0(0-1)$ & 5 \\
Unidentified cestode & -0.10 & 0.54 & 0.85 & $0(0-2)$ & 87 \\
Microsomocanthus (cestode) & -0.02 & 0.05 & 0.75 & $100(0-1000)$ & \\
Intercept & 7.07 & 3.02 & 0.03 & & \\
\hline \hline
\end{tabular}




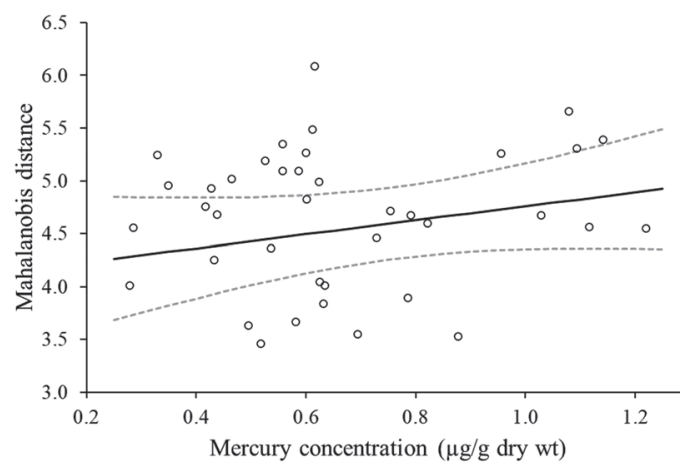

Figure 3. Predicted Mahalanobis fluctuating asymmetry values of 39 adult male Common Eider (Somateria mollissima) mandibles from Cape Dorset, Nunavut, Canada in relation to mercury concentration. The predictive model used median values of Lateriporus, Profilicollis, and Microsomacanthus and reference categorical values for Fimbriarioides and unidentified cestodes. Open circles are the raw data used in the model. Dashed lines represent $95 \%$ confidence interval.

FA in Common Eider mandibles and $\mathrm{Hg}$ concentration or parasite intensity. Our results do not support our initial hypothesis of higher FA with increasing muscle tissue $\mathrm{Hg}$ levels and parasite burden.

Unfortunately, $\mathrm{Hg}$ concentration in adult eider tissues does not necessarily reflect the amount of mercury birds are exposed to during skeletal development. Because birds have several ways of reducing their $\mathrm{Hg}$ load, we are unable to determine the amount of $\mathrm{Hg}$ to which eiders were exposed during development using $\mathrm{Hg}$ levels in the tissues of adult eiders. For instance, adult Cory's Shearwater (Calonectris borealis) deposit dietary $\mathrm{Hg}$ into their feathers (Monteiro and Furness 2001). Reduced brain, muscle, and liver $\mathrm{Hg}$ levels were also found after molting and $\mathrm{Hg}$ excretion in European Starling (Sturnus vulgaris; Whitney and Cristol 2017). The different $\mathrm{Hg}$ elimination processes throughout the avian body could have decreased the $\mathrm{Hg}$ load in the eiders in our study, making adult $\mathrm{Hg}$ levels a poor reflection of $\mathrm{Hg}$ levels experienced during development.

An antagonistic interaction between consumed $\mathrm{Hg}$ and Selenium (Se) during development may have also reduced any impact of $\mathrm{Hg}$ on mandible symmetry. Selenium is found in relatively high levels in Arctic waterfowl (Stout et al. 2002; Braune and Malone 2005), including Common Eiders (Wayland et al. 2001b). Methylmercury is converted to inorganic $\mathrm{Hg}$ in animal tissues, where it may bind to Se and prevent further damage in the animal's body (Eagles-Smith et al. 2009; Scheuhammer et al. 2015). In Japanese Quail (Coturnix japonica) chicks, continuous exposure to $\mathrm{Hg}$ and $\mathrm{Se}$ diets led to dramatic mortality declines while exposure to Hg-only diets led to high mortality (Stoewsand et al. 1974). Studies on Mallard (Anas platyrhynchos; Hoffman and Heinz 1998) and Shaoxing Duck (Anas platyrhynchos domesticus; Ji et al. 2006) also attributed Se exposure and diet to the increases in antioxidant enzymes such as glutathione peroxidase, glutathione, and superoxide dismutase which reduces tissue and neurological damage and promotes $\mathrm{MeHg}$ removal from the body. For our study, Hg and Se intake during development possibly reduced the negative impacts of $\mathrm{MeHg}$ in Common Eiders through increased protection from oxidative stress.

In comparison to other studies, Common Loon (Gavia immer) with higher $\mathrm{Hg}$ burdens $(>40 \mu \mathrm{g} / \mathrm{g}$ ) showed greater feather weight asymmetry compared to adults with smaller $\mathrm{Hg}$ loads $(<10 \mu \mathrm{g} / \mathrm{g}$; Evers et al. 2008). These Hg levels are much greater than the maximum found in our study $(1.2 \mu \mathrm{g} / \mathrm{g})$. Herring et al. (2017) found inconsistent relationships between overall FA and tissue $\mathrm{Hg}$ levels in various water birds. They found no relationships between the overall FA and total blood and feather Hg levels for American Avocet (Recurvirostra americana), Blacknecked Stilt (Himantopus mexicanus), and Caspian Tern (Hydroprogne caspia), but overall FA increased with higher Hg levels in breast feathers and blood for Forster's Tern (Sterna forsteri; Herring et al. 2017). Herring et al. (2017) concluded that different avian structures may exhibit different relationships with $\mathrm{Hg}$ levels in different tissues and that some species may not show relationships with FA and Hg. Further comprehensive studies should determine which species exhibit Hg-related FA by examining multiple structures at once and pinpointing the most affected structure due to contaminant exposure. Although prevalence was high, the amount of mercury found in Common Eiders in our study was quite low compared to other studies $(0.83 \mu \mathrm{g} / \mathrm{g}$ blood $\mathrm{Hg}$; Meattey et al. 2014) that also did not find adverse effects related to mercury.

We also did not find any relationship between FA and any of the helminth intensities in our study. Camphuysen et al. (2002) compiled levels of infection with Profilicollis botulus in Common Eider and found prevalence ranged from 76.7 to $100 \%$ with mean abundance ranging from 30 to 271 worms with a maximum of 1270 parasites in a single bird. Kats et al. (2007) also found P. botulus infection levels in Common Eider (prevalence $=83.8 \%$; mean number $=109$, range $=1-2938)$ far above what we observed, but infection did not contribute significantly to negative effects on body condition, regardless of age. The natural infection rates found in healthy juvenile and 
adult eiders suggest that helminths may not severely impact juvenile growth and development.

The Procrustes ANOVA results indicate moderate measurement error during mandible digitization, which could have contributed to our non-significant results. Van Dongen (2015) showed that high measurement error in FA studies weakens the relationship between the true and estimated individual FA values and leads to biased FA estimates. It is possible that the measurement error in our study resulted in underestimated or overestimated individual FA values, which possibly prevented us from finding significant relationships. Variation among individuals for some of the landmarks potentially led to inconsistencies in landmark digitization for the whole group of individuals, which resulted in higher measurement error. Future studies should focus on increasing sample size, choosing better and more pronounced landmarks, and allocating time to practice digitization before each session to reduce measurement error. If feasible, an alternate method could be used where the mandibles are scanned three-dimensionally and digital techniques used to measure symmetry. Checking all the samples with a pilot study may also be beneficial for determining problematic or appropriate landmarks to use and whether replicates are needed for the main study (Klingenberg 2015).

\section{Author Contributions}

Writing - Original Draft: J.G.P.; Writing - Review \& Editing: C.S. and E.B.; Conceptualization: C.S.; Investigation: J.F.P. and J.G.P.; Methodology: G.G., J.F.P., and C.S.; Resources: G.G., J.F.P., C.S., and E.B.; Formal Analysis: J.F.P., C.S., and E.B.; Funding Acquisition: G.G. and J.F.P.; Visualization: J.G.P.

\section{Acknowledgements}

Thanks to Corey Smereka (University of Alberta) for assistance with equipment, software, and interpretation of the results from the Procrustes ANOVA and to Jocelyn Hudon (Royal Alberta Museum) for support and guidance during this project and Mark Edwards (Royal Alberta Museum) for use of digitizing equipment and computer. Gary Erickson (Royal Alberta Museum) and Delainie Sutherland (Royal Alberta Museum) helped prepare the skulls prior to digitization.

\section{Literature Cited}

AMAP (Arctic Monitoring and Assessment Programme). 2011. AMAP Assessment 2011. Oslo, Norway.

Bishop, C.A., and W. Threlfall. 1971. Helminth parasites of the common eider duck, Somateria mollissima (L.), in Newfoundland and Labrador. Proceedings of the Helminthological Society of Washington 41: 25-35.
Borgsteede, F.H.M., A. Okulewicz, P.E.F. Zoun, and J. Okulewicz. 2005. The gastro-intestinal helminth fauna of the eider duck (Somateria mollissima L.) in The Netherlands. Helminthologia 42: 83-87.

Braune, B.M., and B.J. Malone. 2006. Mercury and selenium in livers of waterfowl harvested in northern Canada. Archives of Environmental Contamination and Toxicology 50: 284-289. https://doi.org/10.1007/s00244005-7093-7

Camphuysen, C.J., C.M. Berrevoets, H.J.W.M. Cremers, A. Dekinga, R. Dekker, B.J. Ens, T.M. Van der Have, R.K.H. Kats, T. Kuiken, M.F. Leopold, and J. Van der Meer. 2002. Mass mortality of common eiders (Somateria mollissima) in the Dutch Wadden Sea, winter 1999/2000: starvation in a commercially exploited wetland of international importance. Biological Conservation 106: 303-317. https://doi.org/10.1016/S00063207(01)00256-7

del Castillo, D.L., V. Segura, D.A. Flores, and H.L. Cappozo. 2016. Cranial development and directional asymmetry in Commerson's dolphin, Cephalorhynchus commersonii commersonii: 3D geometric morphometric approach. Journal of Mammalogy 97: 1345-1354. https://doi.org/10.1093/jmammal/gyw101

Dietz, R., P.M. Outridge, and K.A. Hobson. 2009. Anthropogenic contributions to $\mathrm{Hg}$ levels in present-day Arctic animals - a review. Science of the Total Environment 407: 6120-6131. https://doi.org/10.1016/j.scitotenv.2009. 08.036

Eagles-Smith, C.A., J.T. Ackerman, J. Yee, and T.L. Adelsbach. 2009. Mercury demethylation in waterbird livers: dose-response thresholds and differences among species. Environmental Toxicology and Chemistry 28: 568-577. https://doi.org/10.1897/08-245.1

Evers, D.C., L.J. Savoy, C.R. DeSorbo, D.E. Yates, W. Hanson, K.M. Taylor, L.S. Siegel, J.H. Cooley, M.S. Bank, A. Major, and K. Munney. 2008. Adverse effects from environmental $\mathrm{Hg}$ loads on breeding common loons. Ecotoxicology 17: 69-81. https://doi.org/10.1007/ s10646-007-0168-7

Friend, M., and J.C. Franson. 1999. Field manual of wildlife diseases. General field procedures and diseases of birds (No. ITR-1999-001). Geological Survey, Biological Resources Division, Madison, Wisconsin, USA.

Goudie, R.I., G.J. Robertson, and A. Reed. 2000. Common Eider (Somateria mollissima). In The Birds of North America. Edited by A.F. Poole and F.B. Gill. Cornell Lab of Ornithology, Ithaca, New York, USA. https://doi.org/10.2173/bna.546

Herring, G., C.A. Eagles-Smith, and J.T. Ackerman. 2017. Mercury exposure may influence fluctuating asymmetry in waterbirds. Environmental Toxicology and Chemistry 36: 1599-1605. https://doi.org/10.1002/ etc. 3688

Hoffman, D.J., and G.H. Heinz. 1998. Effects of mercury and selenium on glutathione metabolism and oxidative stress in mallard ducks. Environmental Toxicology and Chemistry 17: 161-166. https://doi.org/10.1002/etc.562 0170204

Hollmén, T., J.T. Lehtonen, S. Sankari, T. Soveri, and M. Hario. 1999. An experimental study on the effects 
of polymorphiasis in common eider ducklings. Journal of Wildlife Diseases 35: 466-473. https://doi.org/10. 7589/0090-3558-35.3.466

Houserova, P., V. Kubáň, S. Kráčmar, and J. Sitko. 2007. Total mercury and mercury species in birds and fish in an aquatic ecosystem in the Czech Republic. Environmental Pollution 145: 185-194. https://doi.org/ 10.1016/j.envpol.2006.03.027

Jenssen, B.M., J.B. Aarnes, K.M. Murvoll, D. Herzke, and T. Nygård. 2010. Fluctuating wing asymmetry and hepatic concentrations of persistent organic pollutants are associated in European shag (Phalacrocorax aristotelis) chicks. Science of The Total Environment 408: 578-585. https://doi.org/10.1016/j.scitotenv.2009.10.036

Ji, X., W. Hu, J. Cheng, T. Yuan, F. Xu, L. Qu, and W. Wang. 2006. Oxidative stress on domestic ducks (Shaoxing duck) chronically exposed in a mercury-selenium coexisting mining area in China. Ecotoxicology and Environmental Safety 64: 171-177. https://doi.org/ 10.1016/j.ecoenv.2005.03.009

Kats, R.K.H., T.K. Christensen, H. Bækgaard, F.H.M. Borgsteede, B.J. Ens, C.J. Camphuysen, E.H.W.G. Meesters, M.F. Leopold, and R.H. Drent. 2007. On the role of gastrointestinal helminths (Amidostomum acutum and Profilicollis botulus) in recent mass mortalities among common eider Somateria mollissima wintering in the Netherlands: a comparison between beached and shot birds. Pages 111-136 in Common Eiders Somateria Mollissima in the Netherlands-the rise and fall of breeding and wintering populations in relation to the stocks of shellfish. Ph.D. thesis, University of Groningen, Groningen, Netherlands.

Klingenberg, C.P. 2003. A developmental perspective on developmental instability: theory, models and mechanisms. Pages 12-34 in Developmental Instability: Causes and Consequences. Edited by M. Polak. Oxford University Press, New York, New York, USA.

Klingenberg, C.P. 2011. MorphoJ: an integrated software package for geometric morphometrics. Molecular Ecology Resources 11:353-357. https://doi.org/10.1111/ j.1755-0998.2010.02924.x

Klingenberg, C.P. 2015. Analyzing fluctuating asymmetry with geometric morphometrics: concepts, methods, and applications. Symmetry 7: 843-934. https://doi.org/ 10.3390/sym7020843

Klingenberg, C.P., M. Barluenga, and A. Meyer. 2002. Shape analysis of symmetric structures: quantifying variation among individuals and asymmetry. Evolution 56: 1909-1920. https://doi.org/10.1111/j.0014-3820.2002.tb 00117.x

Klingenberg, C.P., and L.R. Monteiro. 2005. Distances and directions in multidimensional shape spaces: implications for morphometric applications. Systematic Biology 54: 678-688. https://doi.org/10.1080/10635150590947258

Krabbenhoft, D.P., and E.M. Sunderland. 2013. Global change and mercury. Science 341: 1457-1458. https:// doi.org/10.1126/science. 1242838

Margolis, L., G.W. Esch, J.C. Holmes, A.M. Kuris, and G.A. Schad. 1982. The use of ecological terms in parasitology (report of an ad hoc committee of the American Society of Parasitologists). Journal of Parasitology 68:
131-133. https://doi.org/10.2307/3281335

McLaughlin, J.D. 2008. Cestodes. Pages 261-276 in Parasitic Diseases of Wild Birds. Edited by C.T. Atkinson, N.J. Thomas, and D.B. Hunter. Wiley-Blackwell, Ames, Iowa, USA. https://doi.org/10.1002/9780813804620.ch14

Meattey, D.E., L. Savoy, J. Beuth, N. Pau, K. O'Brien, J. Osenkowski, K. Regan, B. Lasorsa, and I. Johnson. 2014. Elevated mercury levels in a wintering population of common eiders (Somateria mollissima) in the northeastern United States. Marine Pollution Bulletin 86: 229237. https://doi.org/10.1016/j.marpolbul.2014.07.015

Møller, A.P. 1992. Parasites differentially increase the degree of fluctuating asymmetry in secondary sexual characters. Journal of Evolutionary Biology 5: 691-699. https://doi.org/10.1046/j.1420-9101.1992.5040691.x

Monteiro, L.R., and R.W. Furness. 2001. Kinetics, doseresponse, excretion, and toxicity of methylmercury in free-living Cory's shearwater chicks. Environmental Toxicology and Chemistry 20: 1816-1823. https://doi. org/10.1002/etc.5620200827

Nijhout, H.F., and G. Davidowitz. 2003. Developmental perspectives on phenotypic variation, canalization, and fluctuating asymmetry. Pages 3-113 in Developmental Instability: Causes and Consequences. Edited by M. Polak. Oxford University Press, New York, New York, USA.

Nikolov, P.N., B.B. Georgiev, and B.S. Dezfuli. 2008. Cyclophyllidean cysticercoids from Echinogammarus tibaldii (Amphipoda, Gammaridae) from Lake Piediluco, Italy. Acta Parasitologica 53: 215-218. https://doi.org/10. 2478/s11686-008-0017-8

Oleksyk, T.K., J.M. Novak, J.R. Purdue, S.P. Gashchak, and M.H. Smith. 2004. High levels of fluctuating asymmetry in populations of Apodemus flavicollis from the most contaminated areas in Chornobyl. Journal of Environmental Radioactivity 73: 1-20. https://doi.org/10. 1016/j.jenvrad.2003.07.001

Provencher, J.F., H.G. Gilchrist, M.L. Mallory, G.W. Mitchell, and M.R. Forbes. 2016. Direct and indirect causes of sex differences in mercury concentrations and parasitic infections in a marine bird. Science of the Total Environment 551: 506-512. https://doi.org/10.1016/j.sci totenv.2016.02.055

Rodríguez-González, A., A.L. May-Tec, J. Herrera-Silveira, C. Puch-Hau, M. Quintanilla-Mena, J. Villafuerte, I. Velázquez-Abunader, M.L. Aguirre-Macedo, and V.M. Vidal-Martínez. 2020. Fluctuating asymmetry of sclerotized structures of Haliotrematoides spp. (Monogenea: Dactylogyridae) as bioindicators of aquatic contamination. Ecological Indicators 117: 1-10. https:// doi.org/10.1016/j.ecolind.2020.106548

Rózsa, L., J. Reiczigel, and G. Majoros. 2000. Quantifying parasites in samples of hosts. Journal of Parasitology 86: 228-232. https://doi.org/10.1645/0022-3395(2000)086 [0228:qpisoh]2.0.co;2

Sagerup, K., V. Savinov, T. Savinova, V. Kuklin, D.C. Muir, and G.W. Gabrielsen. 2009. Persistent organic pollutants, heavy metals and parasites in the glaucous gull (Larus hyperboreus) on Spitsbergen. Environmental Pollution 157: 2282-2290. https://doi.org/10.1016/j.env pol.2009.03.031 
Sánchez-Chardi, A., M. García-Pando, and M.J. LópezFuster. 2013. Chronic exposure to environmental stressors induces fluctuating asymmetry in shrews inhabiting protected Mediterranean sites. Chemosphere 93: 916923. https://doi.org/10.1016/j.chemosphere.2013.05.056

Scheuhammer, A., B. Braune, H.M. Chan, H. Frouin, A. Krey, R. Letcher, L. Loseto, M. Noël, S. Ostertag, P. Ross, and M. Wayland. 2015. Recent progress on our understanding of the biological effects of mercury in fish and wildlife in the Canadian Arctic. Science of the Total Environment 509: 91-103. https://doi.org/10.1016/j.sci totenv.2014.05.142

Scheuhammer, A.M., M.W. Meyer, M.B. Sandheinrich, and M.W. Murray. 2007. Effects of environmental methylmercury on the health of wild birds, mammals, and fish. Ambio 36: 12-19. https://doi.org/10.1579/00 44-7447(2007)36[12:eoemot]2.0.co;2

Smith, J.H.E., D.A. Cristol, and J.P. Swaddle. 2018. Experimental infection and clearance of coccidian parasites in mercury-exposed zebra finches. Bulletin of Environmental Contamination and Toxicology 100: 8994. https://doi.org/10.1007/s00128-017-2246-8

StataCorp. 2009. Stata Statistical Software: Release 11. StataCorp LP, College Station, Texas, USA.

Stoewsand, G.S., C.A. Bache, and D.J. Lisk. 1974. Dietary selenium protection of methylmercury intoxication of Japanese quail. Bulletin of Environmental Contamination and Toxicology 11: 152-156. https://doi.org/10.1007/bf 01684595

Stout, J.H., K.A. Trust, J.F. Cochrane, R.S. Suydam, and L.T. Quakenbush. 2002. Environmental contaminants in four eider species from Alaska and arctic Russia. Environmental Pollution 119: 215-226. https://doi.org/10. 1016/S0269-7491(01)00336-0

Streets, D.G., M.K. Devane, Z. Lu, T.C. Bond, E.M. Sunderland, and D.J. Jacob. 2011. All-time releases of mercury to the atmosphere from human activities. Environmental Science \& Technology 45: 1048510491. https://doi.org/10.1021/es202765m

Sures, B. 2006. How parasitism and pollution affect the physiological homeostasis of aquatic hosts. Journal of Helminthology 80: 151-157. https://doi.org/10.1079/joh 2006346
Urošević, A., K. Ljubisavljević, and A. Ivanović. 2015. Fluctuating asymmetry and individual variation in the skull shape of the common wall lizard (Podarcis muralis Laurenti, 1768) estimated by geometric morphometrics. Herpetological Journal 25: 177-186.

Van Dongen, S. 2015. Variation in measurement error in asymmetry studies: a new model, simulations and application. Symmetry 7: 284-293. https://doi.org/10.3390/ sym 7020284

Waltho, C., and J. Coulson. 2015. Food and feeding. Pages 99-130 in The Common Eider. Poyser Monographs, London, United Kingdom.

Wayland, M., A.J. Garcia-Fernandez, E. Neugebauer, and H.G. Gilchrist. 2001a. Concentrations of cadmium, mercury and selenium in blood, liver and kidney of common eider ducks from the Canadian Arctic. Environmental Monitoring and Assessment 71: 255267. https://doi.org/10.1023/A:1011850000360

Wayland, M., H.G. Gilchrist, D.L. Dickson, T. Bollinger, C. James, R.A. Carreno, and J. Keating. 2001b. Trace elements in king eiders and common eiders in the Canadian Arctic. Archives of Environmental Contamination and Toxicology 41: 491-500. https://doi. org/10.1007/s002440010276

Whitney, M., and D. Cristol. 2017. Rapid depuration of mercury in songbirds accelerated by feather molt. Environmental Toxicology and Chemistry 36: 3120-3126. https://doi.org/10.1002/etc.3888

Whitney, M.C., and D.A. Cristol. 2018. Impacts of sublethal mercury exposure on birds: a detailed review. Pages 113163 in Reviews of Environmental Contamination and Toxicology, Volume 244. Edited by R. de Voogt. Springer International, Cham, Switzerland. https://doi.org/10.10 07/398_2017_4

Yalkovskaya, L.E., M.A. Fominykh, S.V. Mukhacheva, Y.A. Davydova, and A.V. Borodin. 2016. Fluctuating asymmetry of rodent cranial structures in an industrial pollution gradient. Russian Journal of Ecology 47: 281288. https://doi.org/10.1134/S1067413616030176

Received 4 August 2019

Accepted 21 July 2020

Associate Editor: D.F. McAlpine 